\title{
CREATIVITY AND ENTREPRENEURSHIP AS A DEVICE OF ECONOMIC DEVELOPMENT BY NIGERIAN-BORN ENTREPRENEURS IN TOGO REPUBLIC
}

\author{
Gabriel A. Yalumo \\ DOI: $10.31364 /$ SCIRJ/v8.i11.2020.P1120820 \\ http://dx.doi.org/10.31364/SCIRJ/v8.i11.2020.P1120820
}

\begin{abstract}
This study was established to empirically reveal the creativity and contribution of Nigerian-born entrepreneurs to the expansion of one of the West Africa Countries, Togo Republic through their mode of their business.

To achieve accurate results, selection of respondents was made at some markets using multistage sampling techniques. Data were analyzed via the method of descriptive statistical analysis and analysis of covariance techniques.

The results showed the demographic of age, marital status, interest rate, trade learning area and period stayed in Togo are all significant factors. Furthermore, this study established that products are imported to Togo Republic by some entrepreneurs for sale, while some business managers believed that partnership in their line of work will add to their knowledge in relations to their business activities and makes them learn new skills most time.
\end{abstract}

This study come up with recommendations that the businesses and skills of Nigerian born entrepreneur's activities can be improved upon for expansion in Togo Republic, through economic development, tax payments, employment of both Togolese and other nationalities, improvement in educational facilities and small scale business diversification.

Index Terms: Nigerian Entrepreneur, economic development, GDP growth.

\section{Introduction}

A very cordial relationship exists between entrepreneurial activity and economic development, countries and regions in a greater level of commercialized movement that have experienced high rates of economic development, according to Aronsson (2004) in an interview with David Birch. Davidsson in Reynolds citation (2005) made us to understand that entrepreneurial activity gives a wide explanation between one third and one half of differences in GDP growth between countries. Henderson (2002) states in his view that, entrepreneurship and small business efforts have been projected as revenue to invigorate rural and economically depressed economies via localized job and wealth creation. Globalization procedure has been made in creating rural motivation policies for trade and economic increase not to be really effective. Policies and programmes towards rural economic growth may be overhauled and the method of entrepreneurs in a rural settings to attain adequate impartiality and extra forms of investment gives a substantial gap relative to urban hub entrepreneurs.

The rural law erected towards entrepreneurship provides the utmost chance of providing help to rural areas possibly as contained by the framework of an "industrial ecosystem" where in the policies towards rural financially viable expansion is typically on four powerful pillars.

a. Entrepreneurship instruction and teaching are significant in economic enlargement strategies.

b. Policies requirement to promote the formation of skill and creativity networks that links entrepreneurs to supplies and capital materials.

c. Policies requirement is to guarantee entrance to capital.

Www.scirj.org

(C) 2020, Scientific Research Journal

http://dx.doi.org/10.31364/SCIRJ/v8.i11.2020.P1120820

This publication is licensed under Creative Commons Attribution CC BY. 
d. Infrastructure and organizational maintenance are vital in planning strategies on entrepreneurship.

The world financially viable trends that have led to the disincentives in rural environments have changed a large number of the world's highly developed economies into enterprise economies, according to Ibrahim A. B (1989). Keys as speedy technological transformations, globalization and creativity have led to latest economic development in these economies, which dangles in demand from a regular custom to exceedingly differentiated goods, agricultural food and food classification is no exception. Consequent to the above discussion, dependence on entrepreneurship is on rise to a step of community procedure to revitalize rural financial system, but many are yet to realize what is absolutely understudied is the task of creativity and entrepreneurs played in the society and revival of dying economy.

Arshi and Burns (2016) has postulated that outside of this rural arrangement, the small business competitive edge over the larger organizations in the economic society, it is agreed that the less bureaucratic, more flexible functioning structures of small businesses permit them to swiftly adapt and give responses to innovative progresses in manufacturing, marketing and the remaining specialized point of business. Moreover, bigger organizations ignore investment parts for greatly concentrated manufacturing goods whose limited market potential poses a constraint to the actualization of optimal manufacturing scale and profits. The small organizations then moved in to fill these market gaps.

Nevertheless of their growing value, small business features a complicated challenge to triumph over difficulties in their early years of commencing the business to enable them survive. Business mortality rates have constantly been uppermost in the midst of more fragile newly business enterprises that are still in the newest stage of business growth according to Litvak and Maule (1991).

Entrepreneurship then demands not only purchase of commodity for its own use, but requires a formation of ideas, skills, power and knowledge for the reason of providing job for others and self. It guides and directs to the growth of small, medium and sometimes large-scale businesses on creativity and entrepreneurship. The entrepreneurship on small, medium and large scale are built on advancement in local facilities, services, constructing a basis of regional significant, dependable and sustainable collaborations and enhancing the region's provision of fairness resources.

\section{Objectives of the Study}

The main objective of the study was to evaluate the involvement of Nigerian Citizens in Togo Republic as entrepreneurs and in contributing to the growth of the country through individual business and creativity. The specific objectives are to:

(i) Investigate the capacity of Nigerian run business flow in the study area

(ii) Estimate the consequences of social capital and sundry variables on the business activities results of the Nigerian entrepreneurs in Togo

(iii) Provide the socioeconomic effects and characteristic of the survey respondents and

(iv) Recognize various predicaments faced as entrepreneurs by the survey respondents.

\section{METHODOLOGY AND MATERIALS}

\section{Study Area}

The study is basically in Lome Region of Togo Republic. Lome, which is the capital of Togo Republic, is bounded by Ghana, Benin, Burkina Faso and the Gulf of Guinea. It extends 579 kilometer North from the gulf and it is only 160 kilometer wide at the broadest end. The country consists primarily of two savanna plain regions which separates it by a Southwest-Northwest range of hills (the Chain du Togo). Togo's climate is not stable as it varies from tropical to savanna. The south is humid with temperature ranging from $25^{\circ} \mathrm{C}$ to $32^{\circ} \mathrm{C}(750 \mathrm{~F}$ to $900 \mathrm{~F})$ and in the North $180 \mathrm{C}$ to more than $380 \mathrm{C}(650 \mathrm{~F}$ to $1000 \mathrm{~F})$.

The population of people living in Lome is 1,828,000, according to Lome Urban Area population history, while that of Togo is 8.27 million people at midyear, according to UN data. The two major groups in Togo are the Ewe in the south and the Kabye in the north, but Ewe is spoken in Lome, the capital of Togo and French as her official language, but English are spoken by few Togolese especially in the south and along the Ghana border for business transactions.

www.scirj.org

(C) 2020, Scientific Research Journal

http://dx.doi.org/10.31364/SCIRJ/v8.i11.2020.P1120820

This publication is licensed under Creative Commons Attribution CC BY. 
According to Wikipedia, the economy of Togo has increased to \$5.502 billion of GDP (2019 estimate), \$671 as capital income (2019), with her natural resources is limestone, marble and phosphates.

\section{STUDY DATA}

The data needed for this study were obtained from both primary and secondary sources. The primary data were collected through structured questionnaires from both Nigerian businessmen and women in Lome Region of Togo Republic. The secondary sources were obtained from journals and sundry publication for comprehensive details about the study.

\section{SAMPLING TECHNIQUE}

The sample size for this research work was chosen using a multistage sampling method. The multistage involves bringing together population elements that are geographically closed to one another into natural grouping.

A random sample of questionnaires was selected with complete enumeration of all elements in the selected groups. This involves three stages. The first stage involved the Nigerian citizen entrepreneurs in Attikoume Eebe and Gbadago market, while the second stage involved the traders involved the traders in Port autonomy de Lome, Dekon, Mekafu, Aslama amd Akodewa. The last stage however was the selection of Nigerian entrepreneurs in Herzrananwe, Asiyeye and Assigame Market, Lome.

\section{METHOD OF DATA ANALYSIS}

In this study, both the descriptive statistical analysis and regression of coefficient of variance were employed in the data analysis. Descriptive analysis was adopted to analyze socio-economic characteristics, scope of Nigerian run business activities and the various challenges faced by the entrepreneurs.

The regression of coefficient of various was used to estimate the effect of social capital and sundry variables on business performances

The regression of coefficient of variance is given by:

$\mathrm{CV}=\mathrm{S}_{1} / \mathrm{X}_{1}$

Where $\mathrm{S}=$ Standard error of the estimate for the relevant sundry variables on business performance as measured by annual business profit.

$\mathrm{X}=$ mean value of the individual entrepreneurs

The correlation coefficient was calculated using this formula:

$$
\begin{aligned}
& \mathrm{r}=\left\{\mathrm{n} \Sigma \mathrm{x}_{1} \mathrm{y}_{1}-\left(\Sigma \mathrm{x}_{1}\right)\left(\Sigma \mathrm{y}_{1}\right)\right\} /\left[\left\{\mathrm{n}\left(\Sigma \mathrm{x}_{1}\right)-\left(\Sigma \mathrm{x}_{1}\right)\left\{\mathrm{n}\left(\Sigma \mathrm{y}_{1}\right)-\left(\Sigma \mathrm{y}_{1}\right)\right\}\right]^{-1 / 2}\right. \\
& \mathrm{Y}=\mathrm{f}\left(\mathrm{A}_{1}, \mathrm{~A}_{2}, \mathrm{~A}_{3}, \mathrm{~A}_{4}, \mathrm{~A}_{5}, \mathrm{~A}_{6}, \mathrm{~A}_{7}, \mathrm{~A}_{8}, \mathrm{~A}_{9}, \mathrm{~A}_{10} \varepsilon\right) \\
& \mathrm{A} 1=\operatorname{Sex}(\text { male }=1, \text { otherwise }=0) \\
& \mathrm{A} 2=\text { Age (years) } \\
& \mathrm{A} 3=\text { Marital Status) married }=1, \text { otherwise }=0) \\
& \mathrm{A} 4=\text { educational level (years }) \\
& \mathrm{A} 5=\text { Importation }(\text { goods in quality) } \\
& \text { A6 }=\text { interest Rate }(\%) \\
& \text { A7 }=\text { Learnt trade area }(\text { Nigeria }=1, \text { others }=0)
\end{aligned}
$$

WwW.scirj.org 
A $8=$ Cooperative $($ societies $=1$, otherwise $=00$

A9 $=$ Business type $($ Sole proprietorship $=1$, otherwise $=0)$

A10 $=$ Period stayed $(\mathrm{yrs})$

$\varepsilon=$ Error term

\section{RESULTS AND DISCUSSION}

The results of the research carried out are presented. The method of statistical tools used were percentage, frequently count and regression analysis of covariance. The results were presented in the table and discussion was before the table.

\section{SOCIOECONOMIC CHARACTERISTIC OF THE SURVEY RESPONDENTS}

\section{Distribution of Respondents by age}

Table 1 below provides the classification of the survey respondents by age. The table shows that the respondents in their twenties were 4 percent, those in their thirties were 36 percent, those in their forties were 29.4 percent, those in their fifties were 13.3 percent, those in their sixties and forties were 9.3 percent. The implication was that those in their thirties and forties years were agile in transacting business in Togo Republic, while those in their twenties, fifties and sixties were dependent.

Table 1: Distribution of Respondents by Age

\begin{tabular}{|l|l|l|l|}
\hline Age group & Frequency & Percentage & Cumulative Percentage \\
\hline$<30$ & 3 & 4.0 & 4.0 \\
\hline $30-39$ & 27 & 36.0 & 40.0 \\
\hline $40-49$ & 22 & 29.4 & 69.4 \\
\hline $50-59$ & 10 & 13.3 & 82.7 \\
\hline $60-69$ & 6 & 8.0 & 90.7 \\
\hline$>69$ & 7 & 9.3 & 100 \\
\hline Total & 75 & 100.0 & \\
\hline
\end{tabular}

Source: Field Survey 2019

\section{Distribution of Respondents by sex}

Table 2 presents the distribution of the respondents by sex, showing that 17.3 present of the respondent were female and 82.7 percent were, male. The implication of this findings was that males were more committed to risk and ready to face risk involved in transacting business in a neighbouring country, while their female counterpart were not so involved.

Table 2: Distribution of Respondent by Sex

\begin{tabular}{|l|l|l|l|}
\hline Sex & Frequency & Percentage & Cumulative Percentage \\
\hline Female & 13 & 17.3 & 17.3 \\
\hline Male & 62 & 82.7 & 100.0 \\
\hline Total & $\mathbf{7 5}$ & $\mathbf{1 0 0 . 0}$ & \\
\hline
\end{tabular}

Source: field Survey 2019

\section{Distribution of Respondents by Marital status}

The distribution of respondents by marital status is shown in Table 3. The results gives it that majority of the respondent were married with 82.3 percent and 18.7 percent were single. This indicates that almost all of the entrepreneurs from Nigeria in Togo Republic have family responsibilities.

Table 3: Distribution of respondents by Marital Status

www.scirj.org

(C) 2020, Scientific Research Journal

http://dx.doi.org/10.31364/SCIRJ/v8.i11.2020.P1120820

This publication is licensed under Creative Commons Attribution CC BY. 


\begin{tabular}{|l|l|l|l|}
\hline Status & Frequency & Percentage & Cumulative Percentage \\
\hline Single & 14 & 18.7 & 18.7 \\
\hline Married & 61 & 81.3 & 100.0 \\
\hline Total & 75 & 100.0 & \\
\hline
\end{tabular}

\section{Source: Field Survey 2019}

\section{Distribution of Respondents by Occupation}

Table 4 shows the distribution of the respondents according to their occupation, with the findings that 26.7 percent of the respondents were artisans and 73.3 percent of the remaining respondents to be traders. This implies that the purpose of their stay in Togo Republic is to improve their standard of living and for profit making.

Table 4: Distribution of respondent by occupation

\section{Source: Filed Survey 2019}

\begin{tabular}{|l|l|l|l|}
\hline Occupation & Frequency & Percentage & Cumulative percentage \\
\hline Artisan & 20 & 16.7 & 16.7 \\
\hline Trading & 55 & 73.3 & 100.0 \\
\hline Total & 75 & 100.0 & \\
\hline
\end{tabular}

\section{Educational Attainment of Respondents}

The distribution of the Nigerian-born entrepreneurs in Togo Republic by their educational attainment is provided in Table 5. Evidence revealed that 14.7 percent of the respondents had primary school education and majority of them had secondary school education at 77.3 percent, while 5.3 percent had formal education beyond secondary school level that is NCE and 2.7 percent had ND as their educational attainment.

Table 5: Educational attainment of Respondents

\begin{tabular}{|l|l|l|l|}
\hline Level & Frequency & Percentage & Cumulative percentage \\
\hline Primary & 11 & 14.7 & 14.7 \\
\hline Secondary & 58 & 77.3 & 82.0 \\
\hline NCE & 4 & 55.8 & 97.3 \\
\hline OND & 2 & 2.7 & 100.0 \\
\hline Total & 78 & 100.0 & \\
\hline
\end{tabular}

Source: Field Survey 2019

\section{Scope of Nigerian-born business activities in Togo Republic}

\section{Distribution of respondents by source of goods sold}

Table 6 presents the distribution of the entrepreneurs that imported goods from other counties into Togo Republic. The table showed the bulk of 54.7 percent did not import goods and 45.3 percent of the respondents imported goods offered for sale to people. It indicates that there are needs for the traders to import goods to the country in order to meet up with the needs of people at a particular point in time.

Table 6: Distribution of respondents by source of goods sold

\begin{tabular}{|l|l|l|l|}
\hline Goods & Frequency & Percentage & Cumulative percentage \\
\hline Not importing & 41 & 54.7 & 54.7 \\
\hline Importing goods & 34 & 45.3 & 100.0 \\
\hline Total & 75 & 100.0 & \\
\hline
\end{tabular}

Source: filed Survey 2019

\section{Distribution of Respondents by partnership}

www.scirj.org

(C) 2020, Scientific Research Journal

http://dx.doi.org/10.31364/SCIRJ/v8.i11.2020.P1120820

This publication is licensed under Creative Commons Attribution CC BY. 
Table 7 provides the classification of the survey respondents on partnership basis. Evidence revealed that 38.7 percent did not engage in partnership and the bulk of 61.3 percent were actively involved in partnerships. The indication was that the business transactions go a long way with support from their counterparts, which brings about business development and improvements of their business activities.

Table 7: Distribution of Respondents by partnership

\begin{tabular}{|l|l|l|l|}
\hline Partnership & Frequency & Percentage & Cumulative percentage \\
\hline No & 29 & 38.7 & 38.7 \\
\hline Yes & 46 & 61.3 & 100.0 \\
\hline Total & 75 & 100.0 & \\
\hline
\end{tabular}

\section{Source: Field survey 2019}

\section{Business Performance of Respondents in Togo Republic}

The distribution of the respondents by their performance is presented in Table 8. The findings shows that 2.7 percent had their performance to be fair, 21.3 percent of the respondents had their performance as average and the bulk of 44 percent and 32 percent had their performances good and very good respectively in the area. It suggests that not all the respondents were happy with their business performances in Togo.

Table 8: Performance of respondents in Togo Republic

\begin{tabular}{|l|l|l|l|}
\hline Performance & Frequency & Percentage & Cumulative percentage \\
\hline Fair & 2 & 2.7 & 2.7 \\
\hline Average & 16 & 21.3 & 24.0 \\
\hline Good & 33 & 44.0 & 68.0 \\
\hline Very good & 24 & 32.0 & 100.0 \\
\hline Total & 75 & 100.0 & \\
\hline
\end{tabular}

\section{Source: Field Survey 2019}

\section{How the performance of entrepreneurs can be improved upon}

Table 9 presents the suggestion of entrepreneurs on how their performances can be improved upon. The result indicates that the bulk of 21.3 percent were supporting having more capital for improvement of business in Togo Republic, 8 percent believed that performances has to be increased to aid their performances, 4 percent are expecting support assistance from corporate bodies, 8 percent believes in customers' selection, 10.7 percent believes in hand working, 1.3 percent believes in rapid turnover, 1.0 percent are supporting bulk production, 13.3 percent supports more customers, 5.3 percent believes in tax reduction, 9.3 percent believes in more interest on sale, 2.7 percent supports more importation, 4 percent believes in acquiring instruction from fellow business men, 1.3 percent believes in innovation, 1.3 percent believes in duty commitment, 1.3 believes in support from foreign money exchange bureau linkage and 6.9 percent believes in business expansion.

Table 9: How the performances of the entrepreneurs can be improved upon

\begin{tabular}{|l|l|l|l|}
\hline Improvement & Frequency & Percentage & Cumulative percentage \\
\hline Performances increment & 6 & 8 & 8 \\
\hline Assistance from corporate bodies & 3 & 4 & 12 \\
\hline More capital & 16 & 21.3 & 33.3 \\
\hline Customer's section & 6 & 8 & 41.3 \\
\hline Hard working & 8 & 10.7 & 52.0 \\
\hline Rapid turnover & 1 & 1.3 & 53.3 \\
\hline Bulk production & 1 & 1.3 & 54.6 \\
\hline More customers & 10 & 13.3 & 67.9 \\
\hline Tax reduction & 4 & 5.3 & 73.2 \\
\hline More interest & 7 & 9.3 & 82.5 \\
\hline More importation & 2 & 2.7 & 85.2 \\
\hline
\end{tabular}

www.scirj.org

(C) 2020, Scientific Research Journal

http://dx.doi.org/10.31364/SCIRJ/v8.i11.2020.P1120820

This publication is licensed under Creative Commons Attribution CC BY. 


\begin{tabular}{|l|l|l|l|}
\hline Acquiring instruction & 3 & 4.0 & 89.2 \\
\hline Innovation & 1 & 1.3 & 90.5 \\
\hline Duty commitment & 1 & 1.3 & 91.8 \\
\hline Exchange bureau linkage & 1 & 1.3 & 93.1 \\
\hline Business expansion & 5 & 6.9 & 100.0 \\
\hline Total & $\mathbf{7 5}$ & $\mathbf{1 0 0 . 0}$ & \\
\hline
\end{tabular}

\section{Source: Field Survey 2019}

\section{Return of goods after sales}

Table 10 indicated the return rate by the buyers after they had purchased goods from the traders. The evidence revealed that 50.7 percent of the respondents were not affected by product returns, with $49.3 \%$ of the respondents affected by product returned. The means that the kind of goods offers for sale by each entrepreneur attracts buyer to them. The returned goods were due to spoilage and substandard nature of the products.

Table 10: Return of goods after sales

\begin{tabular}{|l|l|l|l|}
\hline Return of goods & Frequency & Percentage & Cumulative percentage \\
\hline No & 38 & 50.7 & 50.7 \\
\hline Yes & 37 & 49.3 & 100.0 \\
\hline Total & $\mathbf{7 5}$ & $\mathbf{1 0 0 . 0}$ & \\
\hline
\end{tabular}

\section{Source: Field Survey 2019}

\section{Distribution of respondents by means of acquiring skills}

Table 11 below indicates the outcome on the means in which skills was acquired. The results gives 89.3 percent people acquired their skills and knowledge via apprenticeship and 9.4 percent to have acquired their skills via training and workshop and 1.3 percent to have acquired theirs through other means. The implication was that the main aim of the business is to make profits.

Table 11: Distribution of respondents by means of acquiring skills

\begin{tabular}{|l|l|l|l|}
\hline Means & Frequency & Percentage & Cumulative percentage \\
\hline Apprenticeship & 67 & 89.3 & 89.3 \\
\hline Training/workshop & 7 & 9.4 & 98.7 \\
\hline Otherwise & 1 & 1.3 & 100.0 \\
\hline Total & 75 & 100.0 & \\
\hline
\end{tabular}

\section{Source: Field survey 2019}

\section{Distribution of respondents by business experience in years}

Table 11 indicates the distribution of respondents by their business experience in years. The results shows that from 5 years and below was 36 percent, while 34.7 percent were business with business experience of 5 to 10 years, 16 percent were people with experience of 10 to 15years, 5.3 percent were people with business experience of 15 to 20 years, 2.7 percent of the respondent were people with 20 to 25 years of experience, 1.3 percent were people with 25 to 30 years, 30 and above were the respondents with 4 percent of experience. This indicates that experience was a crucial factor that determines the productivity of the traders. This is because, as experience increases, the marketing tactics also increases.

Table 12: Distribution of respondents by business experience in years

\begin{tabular}{|l|l|l|l|}
\hline Years & Frequency & Percentage & Cumulative percentage \\
\hline $1-5$ & 27 & 36.0 & 36.0 \\
\hline $5-10$ & 26 & 34.7 & 70.7 \\
\hline $10-15$ & 12 & 16.0 & 86.7 \\
\hline $15-20$ & 4 & 5.3 & 92.0 \\
\hline $20-25$ & 2 & 2.7 & 94.7 \\
\hline \multicolumn{2}{|l}{} \\
\hline
\end{tabular}

(C) 2020, Scientific Research Journal 


\begin{tabular}{|l|l|l|l|}
\hline $25-30$ & 1 & 1.3 & 96.7 \\
\hline $30 \&$ above & 3 & 4.0 & 100.0 \\
\hline Total & 75 & 100.0 & \\
\hline
\end{tabular}

\section{Source: field survey 2019}

\section{CHALLENGES FACED BY THE ENTREPRENEURS}

\section{Major challenges faced by the entrepreneurs}

Table 13 indicates that the entrepreneurs were faced with some challenges. The evidence revealed the result thus: alienation problems with 26.7 percent, language barrier with 24.0 percent, no access to technology with 14.7 percent, high tax rate with 13.3 and increments on rent payment annually with 21.3 percent. It then gives a direct meaning that there are challenges facing the entrepreneurs in Togo Republic which are discrimination, language barriers, no access to technology, tax increment and relocation from one place to another.

Table 13: Major challenges faced by the entrepreneurs

Source; field survey 2019

\begin{tabular}{|l|l|l|l|}
\hline Problem faced & Frequency & Percentage & Cumulative percentage \\
\hline Alienation & 20 & 26.7 & 26.7 \\
\hline Language barrier & 18 & 24.0 & 50.7 \\
\hline $\begin{array}{l}\text { No access to } \\
\text { technology }\end{array}$ & 11 & 14.7 & 65.4 \\
\hline High tax rate on rent & 10 & 13.3 & 78.7 \\
\hline $\begin{array}{l}\text { Increment } \\
\text { payment annually }\end{array}$ & $\mathbf{7 5}$ & 21.3 & 100.0 \\
\hline Total & $\mathbf{1 0 0 . 0}$ & \\
\hline
\end{tabular}

\section{How to improve operating environment in Togo Republic}

Table 15 indicates how the operating environment in Togo Republic can be improved upon by the indigenous people and strangers to aid business transaction in the area. The results shows that 20 percent of the respondents support economic development, 4 percent support liberal democracy, 6.7 percent of the respondents support tax reduction, 5.3 percent supports good governance, 4 percent supports tax payment, 9.3 percent supports educational improvement, 9.3 percent supports creation of more companies, 4 percent supports more access to technology, 4 percent supports improvement in earning, 5.3 percent supports connectivity of industrial chain, 4 percent supports small sale diversification, 1.3 percent support advertisement on brand of goods, 1.3 percent support public enlightenment on small business, 1.3 percent supports non-involvement in racial discrimination and 10.9 percent supports involvement of private industries to the study area. This implies that if more private companies are allowed in Togo Republic from neighbouring countries, more GNP will be added to the contribution of the study area, employment, educational improvement and creation of companies will also affect the GNP positively.

Table 15: How to improve operating environment in Togo Republic

\begin{tabular}{|l|l|l|l|}
\hline Responses & Frequency & Percentage & Cumulative percentage \\
\hline Economic development & 15 & 20.0 & 20.0 \\
\hline Liberal democracy & 3 & 4.0 & 24 \\
\hline Tax reduction & 5 & 6.7 & 30.7 \\
\hline Good governance & 4 & 5.3 & 36.0 \\
\hline Tax payment & 3 & 4.0 & 40.0 \\
\hline Employment offer & 7 & 9.3 & 47.3 \\
\hline Educational improvement & 7 & 9.3 & 67.9 \\
\hline More access to technology & 3 & 4.0 & 71.9 \\
\hline Improvement in earning & 3 & 4.0 & 75.9 \\
\hline Connectivity of industries & 4 & 5.3 & 81.3 \\
\hline Small scale business & 3 & 4.0 & 85.2 \\
\hline
\end{tabular}

www.scirj.org

(C) 2020, Scientific Research Journal

http://dx.doi.org/10.31364/SCIRJ/v8.i11.2020.P1120820

This publication is licensed under Creative Commons Attribution CC BY. 


\begin{tabular}{|l|l|l|l|}
\hline diversification & & & \\
\hline Advertisement & 1 & 1.3 & 86.5 \\
\hline $\begin{array}{l}\text { Public enlightenment on small } \\
\text { business }\end{array}$ & 1 & 1.3 & 87.8 \\
\hline $\begin{array}{l}\text { Non involvement in racial } \\
\text { discrimination }\end{array}$ & 1 & 1.3 & 89.1 \\
\hline $\begin{array}{l}\text { Participation of private } \\
\text { companies }\end{array}$ & 8 & 10.9 & 100.0 \\
\hline Total & $\mathbf{7 5}$ & $\mathbf{1 0 0 . 0}$ & \\
\hline
\end{tabular}

Source: Field survey 2019

\section{EFFECT OF SUNDRY VARIABLE AND SOCIAL CAPITAL}

\section{Analysis of covariance regression}

Regression coefficient of variance and level of significance of independent variables related to the effect of social capital and sundry variables on the business performance

Table 16: Analysis of covariance regression results

\begin{tabular}{|l|l|l|}
\hline Variables & Regression co-efficient & Standard error \\
\hline Constant & 0.329 & 0.723 \\
\hline Sex & -0.268 & 0.234 \\
\hline Age & $0.024^{* * *}$ & 0.013 \\
\hline Maritstt & $0.649^{*}$ & 0.223 \\
\hline Education & -0.082 & 0.162 \\
\hline Imprttn & -0.273 & 0.186 \\
\hline Intrst & $-0.818^{* * *}$ & 0.333 \\
\hline Lrngtr & $0.327^{* * *}$ & 0.195 \\
\hline Coop & 0.324 & 0.250 \\
\hline Biztyp & -0.274 & 0.232 \\
\hline Pstyd & $-0.021^{* * *}$ & 0.012 \\
\hline R2 $=28.7 \%$ & Adjusted R2 $=17.4 \%$ & F Value $=2.57 *$ \\
\hline
\end{tabular}

*-Significant at $1 \%$ level

**-Significant at $5 \%$ level

***- Significant at $10 \%$ level

Table 16 gives a result that gender, age, marital status, educational level, importation, interest rate, trade learning area, cooperative society, types of business, period on ground at Togo and all projects have significant effects on social capital and sundry variables of the entrepreneurs, but the magnitude of the significant varies. Age is significant at 10 percent, marital status is significant at 1 percent, while interest rate, trade learning area and period on ground are all with negative effect. This indicates that for ages, there is 90 percent confidence that people between age thirties and forties were agile, so the higher the experience, the higher the business activities to the country, married people were more matured and ready to face risk of entrepreneurship in a neighbouring country, also the more the interest rate, trade learning area and period the entrepreneurs had been on ground, the higher the social capital and sundry variables will affect the profit on the businesses, with 99percent confidence, that while all these desired characteristics were present, the entrepreneurs will tend to contribute to the economy of Togo Republic at a higher rate.

The result of this finding has shown that 96 percent of a variation in the sundry variables as explained by the independent variables, while the suitability of the model to give explanation to the data is significant at level of 10 percent.

\section{Summary of major findings}

www.scirj.org

(C) 2020, Scientific Research Journal

http://dx.doi.org/10.31364/SCIRJ/v8.i11.2020.P1120820

This publication is licensed under Creative Commons Attribution CC BY. 
The study has examined the contribution of Nigerian-born entrepreneurs in Togo Republic. Attention has been focused on Ibo and Yoruba tribe of Nigeria, who has been in the country for greener pasture and money in exchange of goods.

This study also found out that some goods were imported into the country by the entrepreneurs and the type of business, marital status, tax, rent, transportation, capital, partnership and interest rate were variables affecting the traders, it also brings about challenges faced by the entrepreneurs and how the operating environment can be improved upon to aid the entrepreneur's business activities in the study area. The study were carefully designed and controlled in order to avoid undesirable bias and so that the result only reflects controlled changes in the value of the variable under study.

The result was analyzed by analysis of covariance, percentage and frequency count. The distribution of the Nigerian-born entrepreneurs by age indicate that 36 percent and 29 percent are thirties and forties were agile for the transaction of business in Togo Republic, a large numbers of the entrepreneurs were Christians and 81.13 percent indicates that the married ones, were with the expectation that their income are directly going on their responsibility. Majority of them were traders with 73.3 percent indicating that Togo republic accommodated people from different countries.

The contribution of the Nigerian-born entrepreneurs were payment of tax to the economy, importation of goods from other countries, rent payment on shop and houses with 96 percent, boarding transportation with 86.7 percent, and the traders chose the country as a place of living for their business activities. The performances of their businesses were rated good and very good with 44 percent and 32 percent respectively, and can be improved upon by getting more capital, hard working, performance increment, getting or acquiring more interest on sales, tax reduction by the Government and securing more customers with 13.3 percent.

\section{RECOMMENDATIONS}

The research findings have posed an understanding that the under listed recommendation will increase the improvement of the Nigerian-born entrepreneurs and the entire Togolese at large.

That economic growth and good governance should be the main objectives of the entrepreneurs.

That the country can receive a great boost through tax payment by the both indigenous people and other entrepreneurs, while it serves as a way to create employment in large quantities for the jobless people.

More private industries from neighouring counties should be given a room to operate and be licensed in Togo Republic for operation.

The entrepreneurs and the indigenous people should be exposed to technology as a matter of priority.

That the government should provide seminar and workshop for entrepreneurs, managers and the traders on annual basis to make them meet up with what is obtainable outside the country.

The government should encourage the citizens of Togo to be educated, with a view to boost their entrepreneurship knowledge.

More importation, customer's selection, duty commitment, interest on capital, bulk production and foreign money exchange bureau should be adopted to improve the operating environment in Togo.

\section{CONCLUSION}

The importance of creativity and entrepreneurship in a particular environment cannot be over emphasized. A large proportion of rural and urban dwellers depend majorly on creativity and entrepreneurship, owing to the fact that it is indicated as a source of growth to people, region, State and country. The study revealed that Nigerian-born entrepreneurs had contributed their quotas to the development of Togo Republic. The desired characteristics were found out to be sex, age, marital status, educational status, importation, interest rate, trade learning area, cooperative, business types and period of time stayed in the country.

Products were being imported to Togo by few entrepreneurs whom they normally used as the products they offer for sale to end buyers, partnership with others, which is very key and through it, the traders gained more knowledge and this made them to know more about what has been affecting their business activities.

$$
\text { www.scirj.org }
$$

(C) 2020, Scientific Research Journal

http://dx.doi.org/10.31364/SCIRJ/v8.i11.2020.P1120820

This publication is licensed under Creative Commons Attribution CC BY. 
The performances of the initiators and entrepreneurs can be improved through more capital, customers' selection, hand working, rapid turnover, bulk production, getting more customers, tax reduction, more interest on trading, more importation, acquiring instruction, innovation, duty commitments, foreign exchange bureau linkage and business expansion.

Research work should be encouraged to look into other uses to which creators of new businesses and entrepreneurs can serve as a means of developing and bringing inovation to rural area in a particular location, region, state and country.

\section{References}

Agbato, J. O. (1990). Managing Organizational Change and Conflict in: Agbato J. O. (Ed.) The nature of Management, Lagos Abiola Bookshops Limited, p 145-154.

Arshi T. \& Burns P (2018) Entrepreneurial Architecture: A framework to promote innovation in large firm. Journal of Entrepreneurship. Entrepreneurship Development Institutue of India.

Aronsson M. (2004). Education Matters - But does Entrepreneurs Education? An interview with David Birch, Academy of Management learning and Education, v3 p289-292.

Arthur, P. K. (2001) Promoting Small scale Industries in Ghana: Development Institutions, Culture and Politics. Department of Political Studies, Kingston, Ontanio.

Balunywa, W. (2001) entrepreneurship and small Business enterprise growth in Uganda, Kampala, Makere University Business School, Kampala.

Burns P. (2016). Entrepreneurship and Small Business: Start u, growth and maturity. Macmilan International Higher Education. London, United Kingdom. $4^{\text {th }}$ Edition.

Davidsson in Reynold P.D. Citation (2005). Small business economics: Entrepreneurship research innovator, coordinator and disseminator. 24 (4).

Henderson, J. (2002) "Building the rural economy with high growth entrepreneurs" Federal Reserve bank of Kansas City Economic Review, v87, n3, pp. 45-70.

Ibrahim A. B, (1986) "Perceived causes of success in Small Businesses”. American Journal of Small business, pg 11-12, 41-50.

Litvak \& Muale (1991). Canadian entrepreneurship: A study of small newly established firms. Calton University, Ottawa, CA.

Olayode, G. O. (2007) Orientation for Business Management and Entrepreneurship Development. Olabisi Onabanjo University, College of Agricultural Sciences Material, Ayetoro Ogun State, Nigeria P 121-129.

www.scirj.org

(C) 2020, Scientific Research Journal

http://dx.doi.org/10.31364/SCIRJ/v8.i11.2020.P1120820

This publication is licensed under Creative Commons Attribution CC BY. 